\title{
VZTAH MEZI VÝSKYTEM BALVANŮ V LEDOVCOVÝCH SEDIMENTECH A CHARAKTEREM PREGLACIÁLNIIHO PODLOŽí V PŘEDPOLÍ RYCHLEBSKÝCH HOR A VE ZLATOHORSKÉ VRCHOVINĚ
}

\author{
Relationship between distribution of boulders in glacigenic sediments and preglacial \\ bedrock on Rychleby Mountains foreland and Zlaté Hory Highlands
}

\author{
Martin Hanáček \\ Geografický ústav, Př́rodovědecká fakulta, Masarykova univerzita, Kotlářská 267/2, 61137 Brno; e-mail: HanacekM@seznam.cz
}

(14-22 Jeseník)

Key words: Pleistocene; sediments of continental glacier; boulders deposition; soft and hard bedrock; Rychleby Mountains foreland and Zlaté Hory Highlands

\begin{abstract}
In Rychleby Mountains foreland and Zlaté Hory Highlands exists relationship between frequency of boulders in glacigenic sediments and character of preglacial bedrock. On the soft bedrock (Neogene sediments, kaolinic granitoid) occurs lodgement of boulders. Glacial sediments on the soft bedrock are therefore characterized by high concentration of boulders. On the hard bedrock (non-kaolinic fresh granitoid, metamorphites) there is no lodgement or the lodgement is sporadic. Glacial sediments on the hard bedrock have therefore lower concentration of boulders. On suitable places the glacier detache from the hard bedrock angular boulders which the glacier deposited in the subglacial mobile deformable bed. Loose local boulders from cracked bedrock or eroded glactectonites and tills into glacifluvial sediments also occurred. In the sediments are occurring small boulders (the size is just above the most coarse gravel) of rocks from Rychleby Mts. and Zlaté Hory Highland which the glacier took over from the preglacial colluvial, alluvial and fluvial sediments.
\end{abstract}

\section{Úvod a metodika}

Kontinentální ledovec pokryl během elsterského zalednění severní předpolí a úpatí Rychlebských hor a severní část Zlatohorské vrchoviny (Nývlt et al. 2011). Balvany, tj. frakce nad $256 \mathrm{~mm} v$ b-ose, se masově vyskytují na kopci Písečník (Sandberg) severně od Javorníku, na plochém návrší Hrouda (Butterberg) z. od Vidnavy a pak zejména $\mathrm{v}$ okolí kaolínových jam mezi Vidnavou a Starou Červenou Vodou (hřbet Blumenberg-Schafberg, Urban 1937). V centrální a j. části Žulovské pahorkatiny se objevují už více rozptýleně, přičemž ale byly zaznamenány i těsně u hranice kontinentálního zalednění jižně od Vápenné (Gába - Pek 1999). Mnohem méně balvanů se nalézá v oblasti mezi Sokolským hřbetem a Zlatohorskou vrchovinou, a to i přes značnou plošnou rozsáhlost, mocnost a rovněž odkrytost ledovcových sedimentů v této oblasti. Na Zlatohorsku se balvany vyskytují jen ojediněle (Budková 1947), avšak zde prŕíčina zčásti spočívá v minimální odkrytosti kvartéru.

Obr. 1a: Poloha lokalit, čísla lokalit - viz text. Modrá linie maximální rozsah kontinentálního zalednění podle Nývlta et al. (2011). b - Schematická mapa předkvarterního podloží studované oblasti. Upraveno podle Pouby et al. (1962) a Chába et al. (2007). A - metamorfity a magmatity, B - granitoidy žulovského masivu, C - neogenní sedimenty.

Fig. 1a: Location of studied sites. Site numbers - see text. Blue line - maximum extent of continental glacier after Nývlt et al. (2011). b - Schematic map prequaternary basement of study area. Modifed after Pouba et al. (1962) and Cháb et al. (2007). A - metamorphites and magmatites, B - granitoids of Žulová Batholith, C - Neogene deposits.

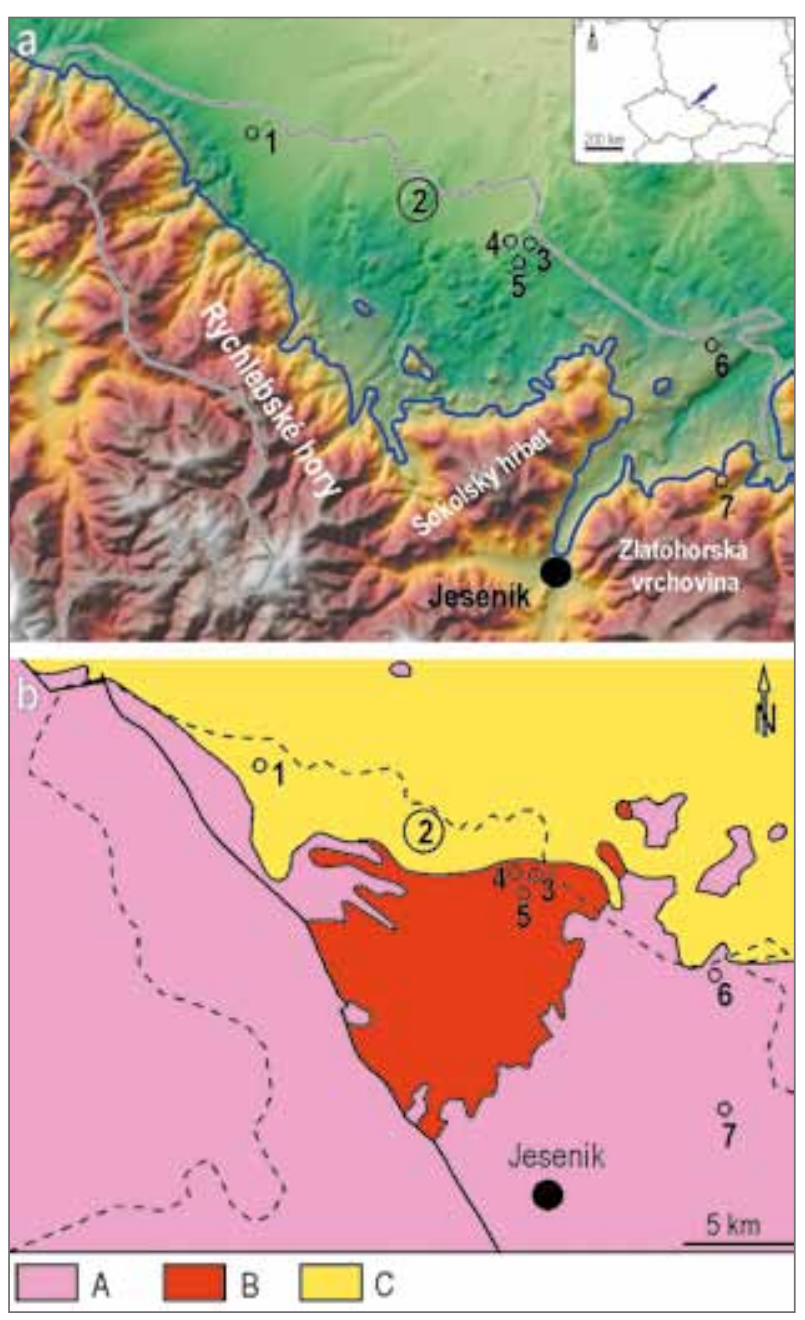


Balvany ve studované oblasti poházejí z baltského štítu a jeho platformy a dále $\mathrm{z}$ krystalinických jednotek Jesenicka a bezprostředně přilehlého Polska. U některých hornin je jejich původ nejistý. Balvany nordické provenience jsou tvořeny prekambrickými granitoidy a metamorfity, mnohem vzácněji proterozoickými a kambrickými pískovci a zcela ojediněle ordovickými vápenci a křídovo-paleocenními pazourky (Hanáček et al. 2007). Balvany jesenického krystalinika tvoří hlavně granitoidy žulovského masivu, amfibolity, mramory, ortoruly a křemen (Gába - Pek 1999; Hanáček et al. 2013). Nejistý původ se vztahuje především na balvany bazaltů, velmi hojné v okolí Javorníku (Gába - Pek 1999).

Cílem tohoto příspěvku je vysvětlení prríčin rozdílné distribuce balvanů v ledovcových sedimentech Jesenicka. Četnost a provenience balvanů byly zkoumány na sedmi lokalitách: Písečník, Hrouda-Heřmanický potok, Stará kaolínová jáma, Štachlovice, Stará Červená Voda,
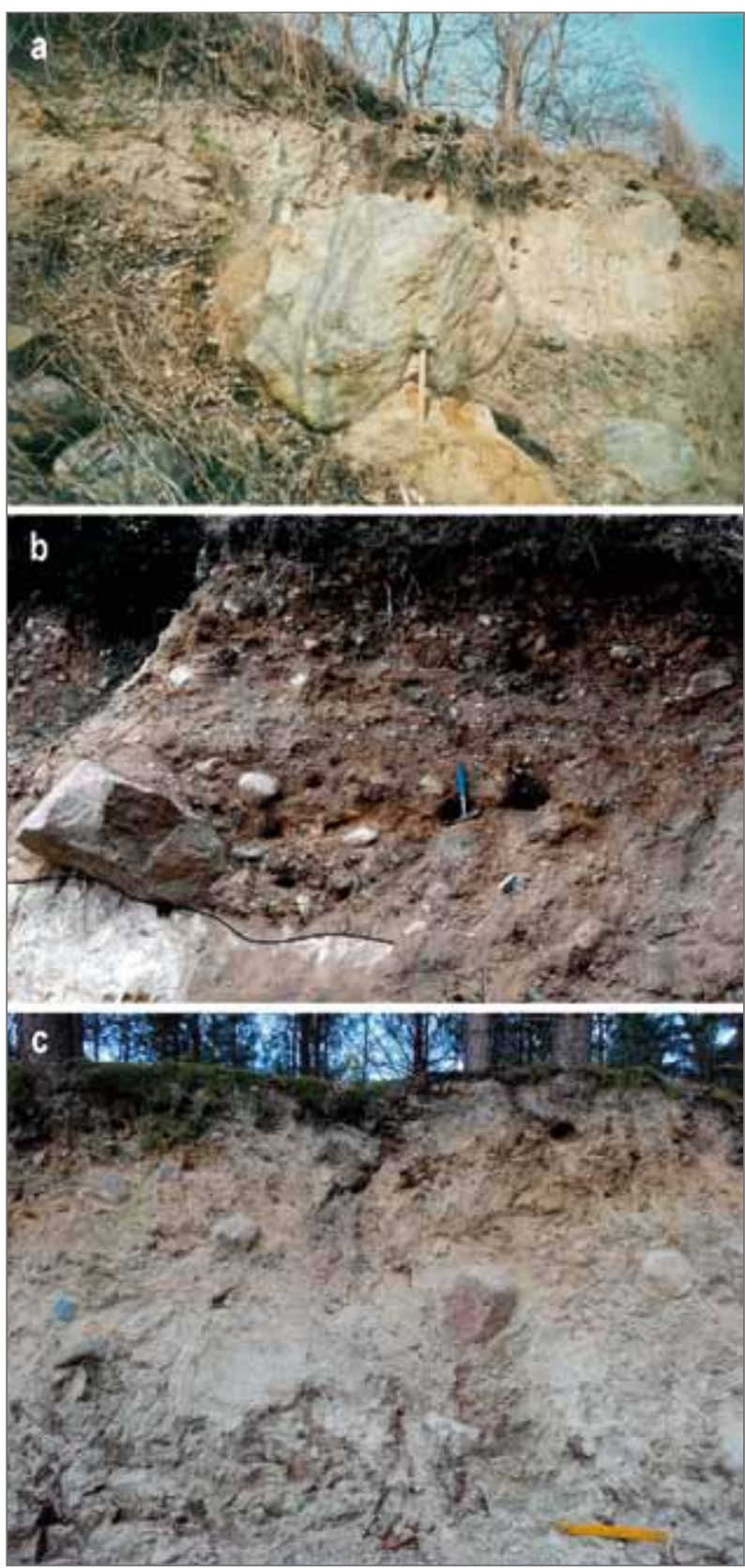

Kolnovice, Javorná (viz obr. 1a). Na každé lokalitě byly začištěny profily a následně faciálně popsány, petrograficky-provenienčně vyhodnoceny a geneticky interpretovány ledovcové sedimenty (Hanáček 2008, 2011, 2012; Hanáček et al. 2013, 2016, nepublikovaná data). Pouze na lokalitě Hrouda-Heřmanický potok byl pro omezenost odkrytí proveden jen základní geologický popis. Na podkladě rekonstrukcí depozičních prostředí jednotlivých lokalit byly vysvětleny prríčiny různé koncentrace balvanů. Získané výsledky umožnily diskutovat tuto problematiku i v dalších částech České republiky zasažených kontinentálním zaledněním. V tomto prríspěvku byly balvany provenienčně rozděleny na místní, tj. odpovídající bezprostřednímu podloží lokalit a cizí, tj. neodpovídající bezprostředně podložním horninám. Mezi cizí patři i balvany hornin jesenického krystalinika, které netvoří předkvartérní podklad konkrétní lokality, stejně jako horniny nordického, polského či nejistého původu.

\section{Výsledky}

\section{Lokalita č. 1: Písečník}

Lokalita představuje drumlin $(288 \mathrm{~m} \mathrm{n}$. m.) ležící severně od Javorníku. Jádro drumlinu tvoří neogenní písky. Na jejich zvlněný povrch nasedají štěrkovité subglaciální a supraglaciální sedimenty (Růžičková et al. 2003; Hanáček et al. 2013). Přímo na kontaktu mezi neogenními písky a ledovcovými sedimenty leží cizí klasty nejhrubšího štěrku a rovněž cizí balvany s délkou mezi prvními desítkami $\mathrm{cm}$ a $200 \mathrm{~cm}$ (obr. 2a, b, viz také Růžičková et al. 2003, obr. 80). Balvany leží na neogenním podkladu ploše, přičemž orientace a-osy balvanů je různá. Okolní štěrkovo-písčito-prachovitý sediment je velmi bohatý na hrubé štěrkové klasty vykazující chaotickou orientaci. Angulární nebo subangulární útržky podložních písků tvoří intraklasty. Balvany se hojně vyskytují i v nadložních supraglaciálních sedimentech. Analýza 61 balvanů ze začištěné stěny odkryvu na temeni drumlinu ukázala

Obr. 2a: Balvan o velikosti $200 \times 140 \times 115 \mathrm{~cm}$ (hrubozrnná, patrně rychlebská rula) na povrchu neogenních písků a na bázi ledovcových sedimentů (ve stěně odkryvu). Lokalita č. 1 Písečník. Stav z roku 2002. b - Balvan nordického granitoidu na povrchu neogenních písků a na bázi ledovcových sedimentů. Černá linie - rozhraní mezi stratigrafickými jednotkami. Lokalita č. 1 Písečník. Foto: D. Nývlt, 2004. c - Neogenní písky a subglaciální trakční till. Rozhraní je nejasné. Uprostřed obrázku zablokovaný malý balvan ålandského rapakivi a několik nejhrubších štěrkových klastů rychlebských hornin. Lokalita č. 2 Hrouda-Heřmanický potok. Měŕítko $20 \mathrm{~cm}$.

Fig. 2a: Boulder $(200 \times 140 \times 115 \mathrm{~cm})$ of pegmatite part of gneiss probably from Rychleby Mts. on the surface of Neogene sands and at the base of glacigenic sediments (in the wall exposure). Site n. 1 Písečník, state in the year 2002. b - Boulder of Nordic granitoid on the surface of Neogene sands and at the base of glacigenic sediments. Black line - boundary between stratigraphic unit. Site n. 1 Písečník. Photo D. Nývlt, 2004. c- Neogene sands and subglacial traction till. Boundary is unclear. In the middle of figure is small lodge boulder of Åland rapakivi and few cobbles of Rychleby Mts. rocks. Site n. 2 Hrouda-Heřmanice stream. Scale $20 \mathrm{~cm}$. 
následující složení: nordika ( 43\%), rychlebské horniny $(\sim 37 \%)$ a provenienčně nejistý bazalt $(\sim 30 \%)$. Balvany hornin z Rychlebských hor mají následující skladbu: gierałtowská rula $(\sim 15 \%)$, křemen $(\sim 3 \%)$, kvarcit $(\sim 1,5 \%)$, amfibolit ( 1,5\%), šedý biotitický granitoid ( 1,5\%). Asi $5 \%$ hornin se nepodařilo zařadit. Největší balvan o rozměrech $200 \times 140 \times 115 \mathrm{~cm}$ tvoří hrubozrnná šedá rula patrně rychlebské nebo velmi blízké polské provenience. Ostatní velké balvany o délce $75-150 \mathrm{~cm}$ jsou téměř výhradně nordika. Rychlebské horniny představují, kromě uvedené výjimky, malé balvany dlouhé první desítky cm. Bazaltové balvany mohou mít několik desítek $\mathrm{cm}$ i více než $1 \mathrm{~m}$. U všech balvanů jasně převládá subangulární a suboválné zaoblení. Přibližně na $8 \%$ balvanů se vyskytují exarační rýhy. Lze je pozorovat na měkkém zvětralém povrchu bazaltů a méně často na nordických balvanech, na nichž se kombinují s ledovcovými ohlazy. Rýhy pro- bíhají bud' všechny paralelně nebo formují skupiny, které vůči sobě zaujímají různou orientaci. Štěrková frakce ledovcových sedimentů je složena hlavně z rychlebských hornin, s podílem nordik max. $12 \%$.

\section{Lokalita č. 2: Hrouda - Heřmanický potok}

Jedná se o rozlehlý plochý drumlin (Pecina et al. 2005) o nadmořské výšce 289 m mezi Vidnavou a Horními Heřmanicemi. Jádro drumlinu budují neogenní jílovito-písčité sedimenty. Svrchní, povrchovou část drumlinu tvoří ledovcové sedimenty (tilly a glacifluviální písky až štěrky) s velmi hojnými balvany nordik o délkách mezi prvními desítkami cm až $150 \mathrm{~cm}$. Geologickou stavbu ukazuje jen několik malých mělkých jam ve svazích návrší. Rozhraní neogenních a pleistocenních sedimentů leží v nadmořské výšce $270 \mathrm{~m}$. Západně od Hroudy jsou však neogenní i pleistocenní sedimenty odhaleny
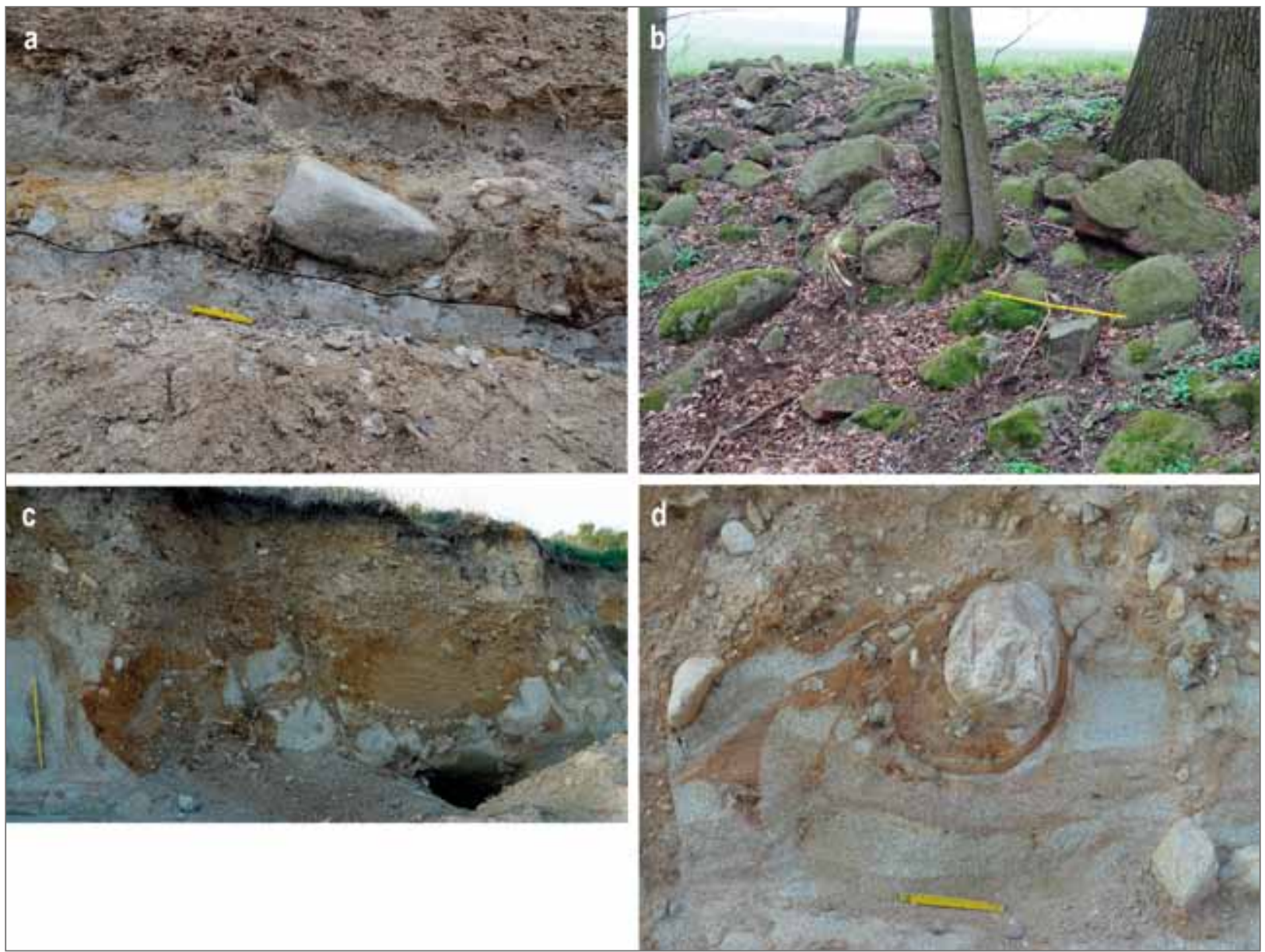

Obr. 3a - Balvan amfibolitu zablokovaný do kaolínového podloží. Za balvanem akumulace hrubého štěrku. Vlevo od balvanu jsou intraklasty kaolínu. V nadloží kaolínu glacifluviální písky. Černá linie - rozhraní mezi stratigrafickými jednotkami. Lokalita č. 3 Stará kaolínová jáma. Měŕítko $20 \mathrm{~cm}$. b - Agrární halda tvořená pouze balvany nordických hornin jv. od Staré kaolínové jámy. Měrítko $100 \mathrm{~cm}$. c - Glacitektonit s angulárními balvany granitoidu žulovského masivu z bezprostředního podloží. Lokalita č. 4 Štachlovice. Měř́tko $60 \mathrm{~cm}$. d - Malý balvan rychlebského kvarcitu zabořený do mezihmoty glacitektonitu. Typická rotační aureola. V podloží angulární klasty granitoidu žulovského masivu. Lokalita č. 4 Štachlovice. Měřítko $20 \mathrm{~cm}$.

Fig. 3a: Amphibolite boulder lodge into kaolin basement. Behind the boulder there is an accumulation of cobbles and pebbles. To the left of the boulder there are intraclasts of kaolin. Glaciofluvial sands overlie kaolin. Black line - boundary between stratigraphic unit. Site n. 3 Old Kaolin Mine. Scale $20 \mathrm{~cm}$. b - Agrarian dump made of Nordic boulders only, south-east from Old Kaolin Mine. Scale $100 \mathrm{~cm}$. c - Glacitectonite with angular boulders of granitoid of Žulová Batholith from immediate basement. Site n. 4 Štachlovice. Scale $60 \mathrm{~cm}$. d - Small boulders of quartzite from Rychleby Mts. lodged into matrix of glacitectonite. Typical rotation aureole. In underlying angular clasts of granitoid from Žulová Batholith. Site n. 4 Štachlovice. Scale $20 \mathrm{~cm}$. 
odkryvem ve hřbetu nad pravým břehem Heřmanického potoka (obr. 2c). Na šedý hutný písek nasedá žlutý masivní kyprý písek mocný $\sim 0,5 \mathrm{~m}$. Oba typy písků jsou podél kontaktu chaoticky promíchané. Svrchní písek obsahuje volně rozptýlené, $10-20 \mathrm{~cm}$ dlouhé klasty a malé balvany cizích hornin (rychlebských hornin, kremene a nordik). Některé balvany a menší klasty jsou zřetelně zabořeny do neogenního podloží. Rozhraní obou stratigrafických jednotek zde probíhá rovněž v nadmořské výšce $\sim 270 \mathrm{~m}$.

\section{Lokalita č. 3: Stará kaolínová jáma}

Rozlehlý neaktivní povrchový důl na kaolín leží jv. od Vidnavy. Přibližně v $270 \mathrm{~m}$ n. m. spočívá na silně kaolinizovaném granitoidu žulovského masivu $\sim 11,5 \mathrm{~m}$ mocné souvrství glacifluviálních a glacilakustrinních sedimentů (Gába 1992). Pleistocenní sekvence začíná většinou $20 \mathrm{~cm}$ mocnou polohou, kterou tvoří většinou až $25 \mathrm{~cm}$ dlouhé klasty cizích (rychlebských a nordických) hornin a podobně velké dokonale zaoblené intraklasty kaolínu. Mezihmota je písčitá. Relativně hojně jsou př́ítomny subangulární balvany cizích hornin o délce $70 \mathrm{~cm}$ (obr. 3a). Některé jsou částečně zabořeny do kaolínu a na svém povrchu nesou chaoticky orientované exarační rýhy. Nad hrubozrnnou bazální polohou pak následují glacifluviální šikmo korytovitě i planárně zvrstvené písky a štěrkovité písky s převahou rychlebských klastů, ale zároveň $s$ mimořádně vysokými podíly nordik - až 29 \% (Hanáček 2008). Profil ve Staré kaolíné jámě odkrývá poměrně plošně rozsáhlou akumulací ledovcových sedimentů (Žáček et al. 2004). Severně, východně i jižně od kaolínové jámy se velmi hojně, místy masově vyskytují cizí balvany o délce $50-200 \mathrm{~cm}$, v jejichž složení jednoznačně dominují nordické horniny (obr. 3b).

\section{Lokalita č. 4: Štachlovice}

Lokalitou je drumlin ( $275 \mathrm{~m}$ n. m.) jehož jádro tvoří výčnělek podložního granitoidu žulovského masivu (Hanáček et al. 2016). Po sv. straně výčnělku leží glacitektonit (Evans et al. 2006), jehož podstatnou složkou jsou angulární balvany místního granitoidu dlouhé až $100 \mathrm{~cm}$ (obr. 3c). Ostré hrany a rohy balvanů a rovněž tak samot- ného výčnělku nasvědčují, že v době vzniku glacitektonitu byl granitoid čerstvý a pevný, ačkoliv je dnes silně zvětralý. Bloky leží ve štěrkovité a písčité mezihmotě. Kromě glacitektonitu ukazuje lokalita písčito-stěrkovou výplň subglaciální kavity, štěrkovitý englaciální-supraglaciální till a terminoglaciální glacifluviální písky a nevytříděné masivní štěrky. Žádné z těchto sedimentů však neobsahují bloky místního granitoidu ani větší cizí balvany. Občas se však vyskytují malé suboválné a subangulární balvany cizího původu, velikostně velmi blízké nejhrubšímu štěrku (cobbles). Tyto balvany se bud' zabořují do okolní mezihmoty za vzniku rotační aureoly (obr. 3d) nebo jsou $\mathrm{v}$ uloženinách volně rozptýleny. $\mathrm{V}$ sedimentech jinak dominují horniny z Rychlebských hor, podíl nordik dosahuje max. $10 \%$.

\section{Lokalita č. 5: Stará Červená Voda}

Malá opuštěná pískovna leží v nadmořské výšce $312 \mathrm{~m}$, asi 0,5 km západně od s. konce Staré Červené Vody, vlevo od silnice do Vidnavy. Facie na lokalitě odpovídají nízkoenergetické distální části výplavové plošiny podle Zielinského - Van Loona (2003). Stř́idají se polohy jemno-hrubozrnného písku a drobného štěrku s mírně ukloněnou až horizontální laminací až tenkým zvrstvením (obr. 4a). Mocnost setů většinou nepřekračuje $10 \mathrm{~cm}$. Méně častá, ale v celém profilu př́itomná, jsou čočkovitá, korytově zahloubená tělesa, mocná až $20 \mathrm{~cm}$. Rozptýleně se objevují intraklasty diamiktonu a dále klasty cizích (rychlebských i nordických) hornin o délce až $20 \mathrm{~cm}$ a nakonec relativně hojné, i přes $100 \mathrm{~cm}$ velké, oválné i subangulární místní balvany granitoidu žulovského masivu (obr. 4b).

\section{Lokalita č. 6: Kolnovice}

Velká aktivní pískovna se stěnou v nadmořské výšce 370-390 m se nachází na z. okraji osady Kolnovice, asi $1 \mathrm{~km}$ s. od Mikulovic. Sedimenty odpovídají proglaciální výplavové plošině s hluboce zaříznutými i širokými koryty (Hanáček 2012). Převážně se jedná o šikmo korytovitě a šikmo planárně zvrstvené písky, štěrkovité písky a štěrky. Masivní štěrky se vyskytují zcela podřízeně. Provenienčně převládá vůči přímému podloží lokality cizí
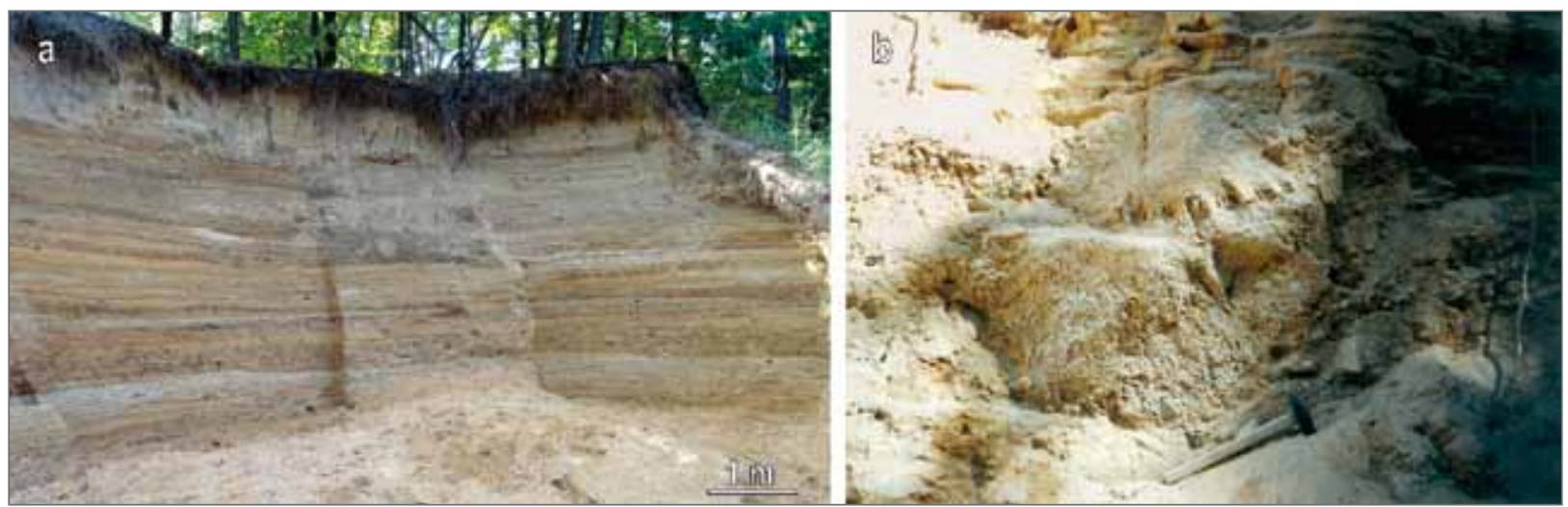

Obr. 4a: Subhorizontálně zvrstvené glacifluviální písky lokality č. 5 Stará Červená Voda. Stav z roku 2011. b - Balvan granitoidu žulovského masivu v glacifluviálních píscích lokality č. 5 Stará Červená Voda. Stav z roku 2001.

Fig. 4a: Glaciofluvial sand with subhorizontal stratification of Site 5 Stará Červená Voda, state in the year 2011. b - Boulder of granitoid of Žulová Batholith in the glacifluvial sands of Site n. 5 Stará Červená Voda. State in the year 2001. 
materiál z okolních horstev, avšak podíl nordik dosahuje v některých polohách až $23 \%$. Větší cizí balvany (nad $50 \mathrm{~cm}$ v a-ose) se zde vykytují velmi vzácně. V hrubých masivních i korytovitě zvrstvených štěrcích se ale často vyskytují malé cizí suboválné až subangulární balvany drakovského a živcového kvarcitu z okolní Zlatohorské vrchoviny a Sokolského hřbetu, které svou velikostí jen málo překračují hranici mezi nejhrubším štěrkem (valouny) a balvany (obr. 5a).

\section{Lokalita č. 7: Javorná}

Opuštěná pískovna leží v nadmořské výšce $510 \mathrm{~m}$, $700 \mathrm{~m}$ vjv. od kóty Bílý kámen $(613 \mathrm{~m})$ ve Zlatohorské vrchovině, asi 4,5 km j. od Mikulovic. Lokalita je interpretována jako štěrkovito-písčitý terminoglaciální výplavový kužel (Hanáček 2011). Ve spodní části odkrytého profilu jsou min. $2 \mathrm{~m}$ mocné hrubé štěrky s velmi hojnými klasty přesahujícími $10 \mathrm{~cm}$ v a-ose. Výše převládají zřetelně jemnozrnnější sedimenty - štěrkovité písky, písky a drobnozrnný štěrk, převážně s šikmým planárním zvrstvením. Hrubý štěrk tvoří ve vyšší části profilu jen $40 \mathrm{~cm}$ mocnou polohu. Provenience sedimentů je nápadně místní - přes $45 \%$ štěrkového materiálu tvoří horniny odpovídající okolní vrbenské skupině, u nichž navíc převažuje subangulární a angulární zaoblení. Podíly nordik se pohybují v prvních \%. V hrubém štěrku se vyskytují malé balvany místního drakovského kvarcitu i cizího živcového kvarcitu ze Sokolského hřbetu, které svou velikostí jen slabě překonávají hranici mezi nejhrubším (valounovým) štěrkem a balvany (obr. 5b). Jiné balvany nebyly zjištěny.

\section{Interpretace}

Podle preglaciálního podloží můžeme lokality rozdělit do dvou skupin (obr. 1b). Do první skupiny lze zařadit lokality s nezpevněným plastickým podložím (Písečník, Hrouda-Heřmanický potok, Stará kaolínová jáma) a do druhé skupiny lokality s pevným horninovým podložím (Štachlovice, Stará Červená Voda, Kolnovice a Javorná). Kromě Štachlovic sice nebyl pevný podklad pleistocénu ve stěnách odkryvů zachycen, ale v případě Staré Červené Vody vystupuje granitoid žulovského masivu jen $450 \mathrm{~m}$ jz. od pískovny, v Kolnovicích je rulové podloží glacifluviálních uloženin zastiženo vrty a v Javorné se jedná o nevelkou akumulaci ledovcových sedimentů ve svahu budovaném metamorfity vrbenské skupiny.

Lokality s nezpevněným preglaciálním podložím se vyznačují velkou hojností balvanů různých velikostí a vůči lokalitám cizí provenience. Tyto balvany leží přímo na povrchu neogenních sedimentů a kaolínu a někdy jsou do plastického podkladu zabořeny. Plochý balvan ve Staré kaolínové jámě je kromě toho mírně nakloněn a za jeho svrchní stranou je koncentrováno množství hrubých štěrkových klastů (obr. 3a). Toto uspořádání, stejně jako samotné zabořování a zablokování balvanů do podloží, je charakteristické pro tzv. lodgement proces, představující základní mechanismus vzniku lodgement tillu (Hart 1995; Benn 1995; Jørgensen - Piotrowski 2003; Bennett - Glasser 2009). Ohlazy a rýhy vznikly při posunování subglaciálního materiálu přes zablokované
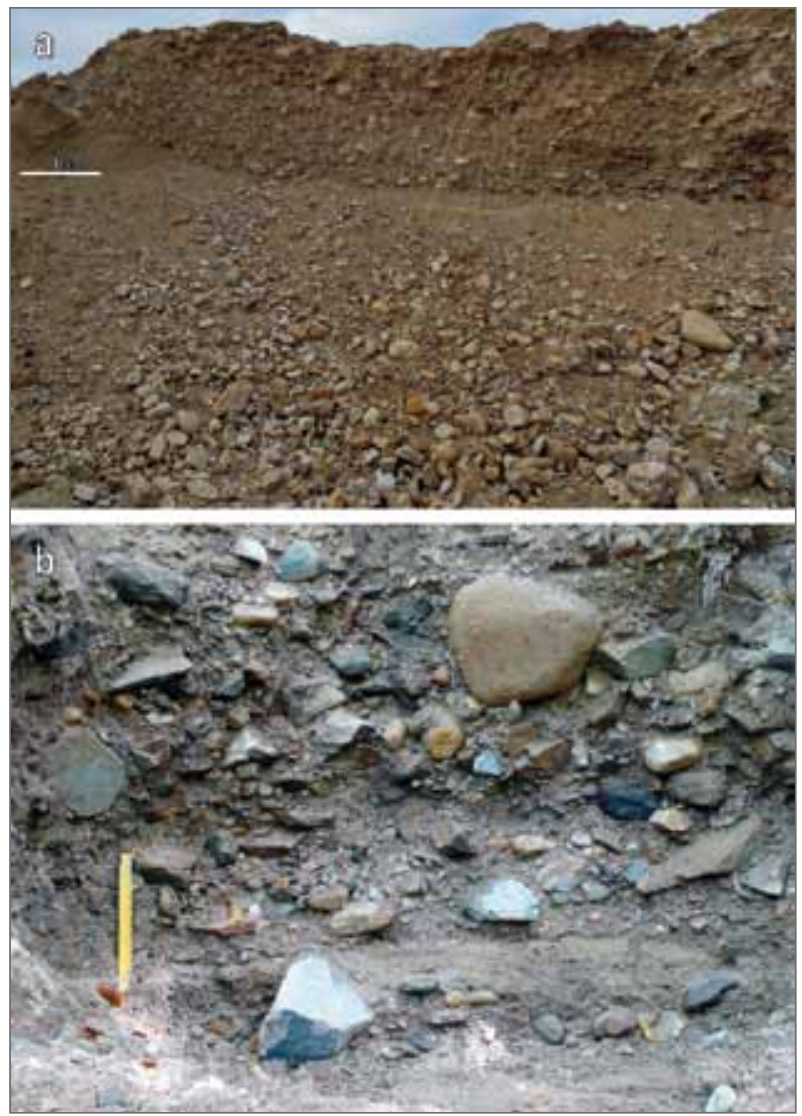

Obr. 5a: Hrubý štěrk vyplňující koryto proglaciální plošiny lokality č. 6 Kolnovice. V osypu malé balvany kvarcitů ze Sokolského hřbetu a Zlatohorské vrchoviny. b - Malé balvany kvarcitů ze Zlatohorské vrchoviny a Sokolského hřbetu v hrubém štěrku terminoglaciálního výplavového kuželu lokality č. 7 Javorná. Měrítko $20 \mathrm{~cm}$.

Fig. 5a: Coarse gravel infill of channel on proglacial outwash plain of Site n. 6 Kolnovice. In the talus there are small boulder of quartzites from Sokolský Ridge and Zlaté Hory Highland. b - Small boulders of quartzites from Zlaté Hory Highland and Sokolský Ridge in the coarse gravel of terminoglacial fan of the Site n. 7 Javorná. Scale $20 \mathrm{~cm}$.

balvany (Benn 1995). Chaotické uspořádání hrubých štěrkových klastů, různosměrnost rýh, četnost intraklastů a zakomponování podložního materiálu bez jeho úplné asimilace do ledovcem transportovaného detritu zase představují typické znaky deformačního tillu a glacitektonitu (Benn-Evans 1996). Subglaciální detrit (mobilní deformační vrstva na bázi ledovce podle Menziese 1989) je pohybem nadložního ledovce deformován a klasty jsou různě otáčeny (Benn 1994, 1995). Procesy zablokování klastů a deformace subglaciální vrstvy detritu však často probíhaly současně, přičemž první proces prodělaly velké klasty a druhý proces menší klasty v mezihmotě (Benn 1994). Bazální balvanitý sediment na Písečníku a sediment nad Heřmanickým potokem lze proto interpretovat jako subglaciální trakční till (Evans et al. 2006) vzniklý souběhem procesů zablokování a deformace. Na lokalitě Stará kaolínová jáma půjde o kombinaci stejných procesů, avšak zde byl subglaciální trakční till zčásti rozplaven tavnou vodou během deglaciace. Rozplavení tillu dokazují glacifluviální sedimenty uložené bezprostředně nad 
hrubou polohou a rovněž dokonalé zaoblení kaolínových intraklastů, které byly v původním tillu pravděpodobně spíše angulární, podobně jako na Písečníku. K reorientování balvanů však tavná voda zřejmě neměla dostatečnou energii a tak balvany a hrubý štěrk představují reziduální horizont (lag) po původním tillu.

Odlišnou situaci nabízejí Štachlovice. Zdejší preglaciální podklad tvořila elevace pevného granitoidu. Ledovec erozně působil na její sv. stranu, ze které odlamoval velké angulární bloky. Tyto pak byly vzápětí uloženy v mobilní deformační vrstvě na bázi ledovce. Jelikož zde ledovec posunoval mobilní deformační vrstvu po pevném podkladu, nedocházelo k zabořování jednotlivých klastů do podloží, ale deformační vrstva byla zablokována jako celek důsledkem tření o podložku. $Z$ tohoto důvodu se místní balvany uložily krátce po svém zapojení do transportu. Na druhou stranu se na této lokalitě nekoncentrovaly větší balvany vůči lokalitě cizí provenience. I přesto, že nebyly v odkryvu nalezeny, budou se velké cizí balvany $\mathrm{v}$ těchto sedimentech vyskytovat, ovšem velmi rozptýleně. Dokladem je jejich občasná př́tomnost na povrchu terénu okolo lokality. Uvnitř deformační vrstvy probíhalo zabořování malých cizích balvanů za současné deformace mezihmoty do podoby rotační aureoly, což je znak subglaciálních tillů vzniklých kombinací zablokování (lodgement) a deformace materiálu na bázi ledovce (Knight 2015). Jelikož kromě bezprostředního podloží byly hlavním zdrojem materiálu subglaciální deformační vrstvy ve Štachlovicích preglaciální fluviální štěrky Vidnávky (Hanáček et al. 2016), jsou několik dm velké balvany tvořeny zejména horninami rychlebského krystalinika.

Do glacifluviálních sedimentů se balvany dostaly fluviální erozí jiných uloženin, např. tillů, nebo i erozí skalního podloží. Nízkoenergetický režim výplavové plošiny ve Staré Červené Vodě kontrastuje s velikostí balvanů místního granitoidu v sedimentech obsažených. Intraklasty diamiktonu a relativní blízkost výchozů žulovského masivu naznačují ve Staré Červené Vodě dva možné způsoby zakomponování balvanů do sedimentů. Balvany mohou představovat relikt rozplavených provenienčně místních glacitektonitů a tillů, podobných těm v sousedních Štachlovicích, nebo mohly být do širokého řečiště uvolněny $\mathrm{z}$ rozpukaných skal $\mathrm{v}$ okolí a podloží plošiny. V kolnovických sedimentech celkově převažuje subangulární a suboválné zaoblení klastů, což společně s petrografickým složením ukazuje, že zde ledovec a následně řeky tavné vody redeponovaly hlavně materiál preglaciálních aluviálních sedimentů (Bušíková 2016). Preglaciální sedimenty byly tvořeny materiálem $\mathrm{z}$ přilehlé Zlatohorské vrchoviny a Sokolského hřbetu. V Javorné lze zase podle pozice pod horským sedlem předpokládat redepozici koluviálních uloženin, čemuž na této lokalitě nasvědčuje vysloveně místní původ většiny materiálu a jeho slabé zaoblení (Hanáček 2011). V Javorné tedy balvany drakovského kvarcitu velikostně, petrograficky i tvarově odpovídají balvanům okolních kamenitých svahovin. Vzácně se ale objevují i malé suboválné balvany živcového kvarcitu s původem totožným s místními balvany v Kolnovicích. Pro glacifluviální sedimenty
Kolnovic i Javorné tedy byly zdrojem materiálu štěrkem bohaté preglaciální uloženiny, po jejichž zakomponování do mobilní deformační vrstvy na bázi ledovce relativní podíl provenienčně cizích balvanů klesl. V případě Kolnovic se navíc jedná o dobře vyvinuté fluviální prostředí široké proglaciální plošiny, kde po většinu období vývoje převládaly energetické podmínky kompetentní $\mathrm{k}$ transportu a depozici štěrkové a pískové frakce. Velké cizí balvany se do sedimentů dostaly bud' jen podél okrajů plošiny, při erozi jiných sedimentů, např. tillů, nebo během mimořádně intenzivních povodní. Jelikož se parametamorfity v podloží kolnovických glacifluviálních sedimentů balvanitě nerozpadaly podobně jako granitoidy v podloží sedimentů ve Staré Červené Vodě, neuvolňovaly se do proglaciálních sedimentů u Kolnovic větší balvany podložní horniny.

\section{Diskuze}

Na Jesenicku odpovídají oblasti s nejhojnějším výskytem balvanů (Urban 1937) ledovcovým sedimentům $s$ nezpevněným plastickým podložím. Kromě neogenních sedimentů a kaolínu je větší akumulace balvanů doložena nad mocnějšími polohami detritického eluvia granitoidů žulovského masivu (Prosová 1981).

Rozdílná četnost balvanů je typická i pro zbylé oblasti České republiky zasažené kontinentálním zaledněním. Balvany se velmi hojně se vyskytují v glacifluviálních píscích i tillech Hlučínska (Vitásek 1926; Kroutilík 1958). Množství balvanů bylo odkryto z podobných sedimentů u Václavovic a Muglinova v Ostravské pánvi (Vitásek 1938; Svoboda et al. 1964, tab. 102). Zatím největší balvan $\mathrm{z}$ ledovcových sedimentů České republiky $s$ rozměry $320 \times 250 \times 155 \mathrm{~cm}$ ležel přímo na neogenních jílech, na bázi $2 \mathrm{~m}$ mocné vrstvy patrně glacifluviálního štěrku v Ostravě-Kunčicích (Linhart 1956). Na celém Hlučínsku a Ostravsku jde vždy o balvany vůči podloží cizí s jednoznačnou dominancí nordik a ojedinělými polskými horninami (Vašičková - Rozehnal 2004). Preglaciální podloží většiny zmíněného území tvoří nelitifikované písčito-jílovité neogenní sedimenty. Situace tedy připomíná jesenické lokality s nezpevneným podložím. Jediný rozdíl spočívá v jemnozrnnosti tillů i glacifluviálních sedimentů Ostravska a Hlučínska (Růžičková et al. 2003), která je ovšem podmíněna zrnitostí zdrojového materiálu, tj. právě neogenních uloženin. Na Jesenicku byla velká část horského předpolí pokryta preglaciálními koluviálními, aluviálními a fluviálními štěrky, které poskytly subglaciální deformační detritické vrstvě dostatek hrubozrnných klastik.

Studovaným lokalitám je podobná rovněž situace ve Šluknovské pahorkatině, kde se ledovec pohyboval převážně po pevném krystalinickém podloží a balvany jsou zde velmi vzácné. Vyskytují se především v subglaciálních tillech u Rožan, kde tyto tilly nasedají na písčité eluvium lužického granodioritu (Nývlt - Opletal 2002; Opletal et al. 2006). Nordické i místní balvany o délce max. $50 \mathrm{~cm}$ zde byly při subglaciálním transportu pravděpodobně zablokovány právě o písčité eluvium. Subglaciální tilly v Rožanech představují lodgement a melt-out typy 
(Nývlt 2008), takže proces zafixování klastů o podložku zde lze předpokládat.

Mechanizmus zablokování balvanů do měkkého podloží nebude jedinou příčinou jejich hojného výskytu na všech lokalitách známých jako naleziště ledovcem transportovaných balvanů. Některé lokality s množstvím provenienčně vzdálených balvanů mají zcela nebo částečně pevné preglaciální podloží, např. Hrozová, Bohušov, Jaktař, Pálkovice u Místku (Urban 1937; Vitásek 1938; Hejtman 1939). Unikátní lokalitou je dnes opuštěná pískovna u Jítravy, asi $1,5 \mathrm{~km}$ z. od Jítravského sedla v Ještědském hřbetu. $\mathrm{V}$ pískovně se hojně nacházejí balvany místních pískovců o délce až několika m (např. Svoboda et al. 1964, tab. 99; Macoun - Králík 1995). Balvany se $\mathrm{v}$ Jítravě vyskytují masově i přes pevné horninové podloží ledovcových sedimentů. V tomto případě se však jedná o geomorfologicky podmíněný, na našem území ojedinělý jev. Ledovcový lalok prostoupil Jítravským sedlem, přičemž se na jeho čele akumulovalo množství balvanitého materiálu ze svahů nad sedlem. Po překonání sedla ledovec akumuloval místní terminoglaciální materiál jako čelní morénu (Nývlt et al. 2011).

\section{Závěr}

$\mathrm{Na}$ Jesenicku existuje vztah mezi charakterem preglaciálního podloží a hromadným výskytem balvanů v nadložních ledovcových sedimentech. V oblastech $s$ nezpevněným, plastickým podložím docházelo při ledovcovém transportu k zablokování balvanů do měkkého podkladu a tím ke koncentraci balvanů na těchto místech. Jelikož nezpevněnost podkladu zabraňovala, aby z něj ledovec mohl odlomit a vzápětí uložit balvany místní horniny, jsou všechny balvany vưči tomuto podkladu cizí. Z podloží byly derivovány jen nelitifikované intraklasty. $\mathrm{Na}$ druhou stranu v oblastech s pevným podložím k blokování balvanů o preglaciální podloží nedocházelo vůbec nebo probíhalo jen omezeně a spíše uvnitř subglaciální deformační vrstvy. $Z$ tohoto důvodu se provenienčně cizí balvany nad pevným podložím lokálně nekoncentrovaly a jsou v sedimentech rozptýleny rovnoměrněji, tj. relativně řidčeji. Puklinatost pevného podloží místy umožňovala vznik velkých, provenienčně vysloveně místních balvanů. Na lokalitách s pevným podložím bez primární blokovité odlučnosti velké místní balvany nevznikaly. Pokud byly jedním ze zdrojů materiálu pro subglaciální deformační vrstvu starší koluviální, aluviální či fluviální sedimenty, pak výsledné ledovcové sedimenty obsahují drobné balvany krystalinických hornin z Rychlebských hor a Zlatohorské vrchoviny.

Je pravděpodobné, že nezpevněné podloží zapříčinilo regionální nabohacení provenienčně cizích balvanů rovněž na Ostravsku a Hlučínsku a lokální nabohacení provenienčně cizích i místních balvanů u Rožan na Šluknovsku.

\section{Poděkování}

Výzkum byl podpořen projektem ECOPOLARIS, číslo CZ.02.1.01/0.0/0.0/16_013/0001708 financovaném Ministerstvem školství, mládeže a tělovýchovy České republiky. Děkuji Martinu Lulákovi (Jihočeská univerzita a Masarykova univerzita) za preklad anglických částí textu.

\section{Literatura}

Benn, D. I. (1994): Fluted moraine formation and till genesis below a temperate valley glacier: Slettmarkbreen, Jotunheimen, southern Norway. - Sedimentology, 41, 279-292.

Benn, D. I. (1995): Fabric signature of subglacial till deformation, Breidamerkurjokull, Iceland. - Sedimentology, 42, 735-747.

Benn, D. I. - Evans D. J. A. (1996): The interpretation and classification of subglacially-deformed materials. - Quaternary Science Reviews, 15, 23-52.

Bennett, M. - Glasser, N. (2009): Glacial geology. - 385 s. Wiley-Blackwell.

Budková, M. (1947): Bludné balvany v okolí Krnova a Cukmantlu. - Sborník Československé společnosti zeměpisné, 52, 92-95.

Bušíková, Z. (2016): Vliv zrnitosti na sedimentárně-geologické vlastnosti glacifluviálních sedimentů: př́kladová studie z lokality Kolnovice. - MS, bakalářská práce. Př́rodovědecká fakulta Masarykovy univerzity. Brno.

Evans, D. J. A. - Phillips, E. R. - Hiemstra, J. F. - Auton, C. A. (2006): Subglacial till: Formation, sedimentary characteristics and classification. - Earth-Science Reviews, 78, 115-176.

Gába, Z. (1992): Profil ledovcovými uloženinami u Vidnavy ve Slezsku. - Časopis Slezského muzea (A), 41, 167-172.

Gába, Z. - Pek, I. (1999): Ledovcové souvky moravskoslezské oblasti. - 111 s. Okresní vlastivědné muzeum v Šumperku.

Hanáček, M. (2008): Valounové analýzy glacifluviálních sedimentů na lokalitě Stará kaolínová jáma u Vidnavy na Jesenicku. Časopis Slezského zemského muzea (A), 57, 222-236.

Hanáček, M. (2011): Sedimenty terminoglaciálního kuželu v údolí Javorné na Zlatohorsku. - Acta Musei Moraviae, Scientiae geologicae, 96, 61-86. 
Hanáček, M. (2012): Glacifluviální výplavová plošina u Kolnovic a její srovnání s terminoglaciálními kužely mezi Sokolským hřbetem a Zlatohorskou vrchovinou u Jeseníku. - Geologické výzkumy na Moravě a ve Slezsku 19, 17-25.

Hanáček, M. - Engel, Z. - Procházková, B. (2016): Vývoj ledovcových sedimentů na kontaktu s žulovským masivem ve Štachlovicích u Vidnavy. - Geologické výzkumy na Moravě a ve Slezsku, 23, 13-23.

Hanáček, M. - Gába, Z. - Nývlt, D. (2007): Der Findlingsgarten in Velká Kraš im Jeseník-Gebiet (Tschechien). - Geschiebekunde aktuell, 23, 3, 70-77.

Hanáček, M. - Nývlt, D. - Nehyba, S. (2013): Písečník u Javorníku - drumlin se zachovalou sukcesí subglaciálních a supraglaciálních sedimentů. - Geologické výzkumy na Moravě a ve Slezsku, 20, 22-29.

Hart, J. K. (1995): Subglacial erosion, deposition and deformation associated with deformable beds. - Progress in Physical Geography, 19, 2, 173-191.

Hejtman, B. (1939): Bludné balvany v Opavském Slezsku. - Časopis vlasteneckého spolku muzejního v Olomouci, 52, 149 -155.

Cháb, J. - Stráník, Z. - Eliášs, M. (2007): Geologická mapa České republiky 1 : 500 000. - Česká geologická služba. Praha.

Jørgensen, F. - Piotrowski, J. A. (2003): Signature of the Baltic Ice Stream on Funen Island, Denmark during the Weichselian glaciation. - Boreas, 32, 242-255.

Knight, J. (2015): Subglacial processes from drumlins in Clew Bay, western Ireland. - Earth Surface Processes and Landforms, $41,277-288$.

Kroutilík, V. (1958): Nález největších bludných balvanů na Hlučínsku. - Přírodovědecký sborník Ostravského kraje, $19,312-315$. Linhart, J. (1956): Největší bludné balvany u nás a jejich původ. - Věda a život, 4, 163-165.

Macoun, J. - Králík, F. (1995): Glacial history of the Czech Republic. - In: Ehlers, J. - Kozarski, S. - Gibbard, P. L. (eds): Glacial Deposits in North-East Europe, 389-405, A.A. Balkema.

Menzies, J. (1989): Subglacial hydraulic conditions and their possible impact upon subglacial bed formation. - Sedimentary Geology, 52, 125-150.

Nývlt, D. (2008): Paleogeografická rekonstrukce kontinentálního zalednění Šluknovské pahorkatiny. - MS, doktorská disertační práce. Př́rodovědecká fakulta Univerzity Karlovy. Praha.

Nývlt, D. - Engel, Z. - Tyráček, J. (2011): Pleistocene glaciations of Czechia. - In: Ehlers, J. - Gibbard, P. L. - Hughes, P. D. (eds): Quaternary Glaciations - Extent and Chronology Part IV - a closer look. Developments in Quaternary Science, 37-46, Elsevier.

Nývlt, D. - Opletal, M. (2002): Nové nálezy nordických hornin ve Šluknovském výběžku. - Zprávy o geologických výzkumech $\mathrm{v}$ roce $2001,35,139-142$.

Opletal, M. - Adamová, M. - Burda, J. - Dušek, K. - Fediuk, F. - Chlupáčová, M. - Knobloch, E. - Kořán, V. - Manová, M. - Nekovařík, Č. - Nývlt, D. - Rambousek, P. - Šalanský, K. (2006): Vysvětlivky k základní geologické mapě České republiky $1: 25$ 000. List 02-212 Horní Poustevna a 02-221 Šluknov. - Česká geologická služba. Praha.

Pecina, V. - Čurda, J. - Hanáček, M. - Kočandrle, J. - Nývlt, D. - Opletal, M. - Skácelová, D. - Skácelová, Z. - Večeřa, J. - Žáček, V. (2005): Základní geologická mapa České republiky 1 : 25000 list 14-221 Žulová s Vysvětlivkami. - MS, Česká geologická služba.

Pouba, Z. - Dvořák, J. - Kužvart, M. - Mísař, Z. - Musilová, L. - Prosová, M. - Röhich, P. - Skácel, J. - Unzeitig, M. (1962): Vysvětlivky k přehledné geologické mapě ČSSR 1:200 000, list M-33-XVIII Jeseník. - Ústřední ústav geologický.

Prosová, M. (1981): Oscilační zóna kontinentálního ledovce. Jesenická oblast. - Acta Universitatis Carolinae, Geologica, 3, $265-294$.

Růžičková, E. - Růžička, M. - Zeman, A. - Kadlec, J. (2003): Kvartérní klastické sedimenty České republiky. Struktury a textury hlavních genetických typů - 92 s. Česká geologická služba. Praha.

Svoboda, J. - Dvořák, J. - Havlena, V. - Havlíček, V. - Horný, R. - Chlupáč, I. - Klein, V. - Kopecký, L. - Malecha, A. - Malkovský, M. - Soukup, J. - Tásler, R. - Václ, J. - Žebera, K. (1964): Regionální geologie ČSSR. Díl I. Český masív. Svazek 2. Algonkium - kvartér. - 543 s. Ústřední ústav geologický. Praha.

Urban, K. (1937): O bludných balvanech v Opavském Slezsku a na Hlučínsku. - Časopis vlasteneckého spolku muzejního v Olomouci, 50, 40-45.

Vašičková, J. - Rozehnal, T. (2004): Pustkovecký bludný balvan. - Geologické výzkumy na Moravě a ve Slezsku, 11, 10-11.

Vitásek, F. (1926): Morfologický vývoj Hlučínska. - Spisy vydávané Př́rodovědeckou fakultou Masarykovy university, 66, 3-38.

Vitásek, F. (1938): Morfologický vývoj Těšínského Podbeskydí. - Spisy vydávané Př́rodovědeckou fakultou Masarykovy university, 250, 3-18.

Zielinski, T. - Van Loon, A. J. (2003): Pleistocene sandur deposits represent braidplains, not alluvial fans. - Boreas, 32, 590-611.

Žáček, V. - Čurda, J. - Kočandrle, J. - Nekovař́ík, Č. - Nývlt, D. - Pecina, V. - Skácelová, D. - Skácelová, Z. - Večeřa, J. (2004): Základní geologická mapa České republiky 1 : 25000 list 14-222 Vidnava s Vysvětlivkami. - Česká geologická služba. Praha. 